\title{
Dinamika Kerukunan Antar Umat Beragama Eksistensi Masyarakat Islam di Bali Pasca Bom Bali Tahun 2002-2012
}

\author{
Wildaniyati $^{{ }^{*}}$, Fransiska Dewi Setiowati Sunaryo ${ }^{2}$ \\ ${ }^{12}$ Program Studi Ilmu Sejarah Fakultas Ilmu Budaya Universitas Udayana \\ ${ }^{1}$ [ukhtiwildaniyati@ymail.com] 2[ fransiska.d3w1@gmail.com] \\ *Corresponding Author
}

\begin{abstract}
On Saturday 12 October 2002, at Banjar Lagian Kelod, Kuta, the Bali Bombing explosion occurred. This is an early event that becomes a long struggle between crisis and harmony. The crisis that occurred as a threat to economy and social harmony that has been built in the Balinese society. Series of bombing incidents is not only of course, but also the cracking of Muslim relations with Hindus in Bali. The several concepts used in this study are collective behavior, norms and corporate actors. The methodology used is the oral history method. Research methods and sources include heuristics, criticism, interpretation and historiography. The results reveal there are some disquiets experienced by Muslim community post bomb, including on the social, security, and economic aspects. Similarly, there are some recovery activities conducted by the Ulama in Bali post Bali Bombing, among others by conducting musyawarah, socialization, pengajian, and other social activities, in this case done to restore confidence and re-recognize the existence of Islamic society post Bali Bombing. Collective behavior, corporate norms and actors are the reasons behind the Balinese attitude towards the Islamic community in the face of Bali Bombing.
\end{abstract}

Keywords: Islamic society, Bali society, Bomb Bali, social harmony, recovery

\begin{abstract}
Abstrak
Pada hari Sabtu tanggal 12 Oktober 2002 tepatnya di Banjar Lagian Kelod, Kuta, terjadi ledakan Bom Bali. Peristiwa tersebut merupakan peristiwa awal yang menjadi pergulatan panjang antara krisis dan harmoni. Krisis yang terjadi dianggap sebagai ancaman terhadap ekonomi dan harmoni sosial yang sudah terbangun dalam masyarakat Bali. Rentetan peristiwa pengeboman itu bukan saja menimbulkan efek ketakutan, tetapi juga retaknya hubungan umat Islam dengan umat Hindu di Bali. Adapun beberapa konsep yang digunakan dalam penelitian ini adalah perilaku kolektif, norma dan aktor korporat. Metodologi yang digunakan adalah metode sejarah lisan. Metode penelitian dan sumber meliputi heuristik, kritik, interpretasi dan historiografi. Hasil penelitian mengungkapkan bahwa ada beberapa keresahan yang dialami masyarakat Islam pasca Bom Bali, diantaranya pada segi sosial, keamanan, dan ekonomi. Begitu juga ada beberapa kegiatan recovery yang dilakukan oleh para Ulama yang ada di Bali pasca Bom Bali, antara lain dengan melakukan musyawarah, sosialisasi, pengajian, dan kegiatan sosial lainnya, dalam hal ini dilakukan guna mengembalikan kepercayaan dan kembali mengakui keberadaan masyarakat Islam pasca Bom Bali. Perilaku kolektif, norma dan aktor korporat adalah alasan yang melatarbelakangi sikap masyarakat Bali terhadap masyarakat Islam dalam menghadapai peristiwa Bom Bali.
\end{abstract}

Kata Kunci : masyarakat Islam, masyarakat Bali, Bom Bali, harmoni sosial, recovery

\section{Latar Belakang}

Pada hari Sabtu tanggal 12 Oktober

2002 tepatnya di Banjar Legian Kelod,
Kuta, Bali terjadi ledakan bom. Pengeboman yang menewaskan 183 orang diantara 53 orang korban berasal 
dari Australia. Peristiwa tersebut merupakan awal yang menjadi pergulatan panjang antara krisis dan harmoni, krisis yang terjadi dianggap sebagai ancaman terhadap ekonomi dan harmoni sosial yang sudah terbangun dalam masyarakat Bali. Dalam upaya mencegah terjadinya hal tersebut, pada pertemuan antara Wali Kota dengan camat, lurah kepala desa, bendesa adat se-Kota Denpasar dan Forum Kerukunan Antar Umat Beragama, Wali Kota Denpasar Anak Agung Ngurah Puspayoga menghimbau warga supaya tidak mudah terpancing isu-isu yang merusak persatuan dan tidak melakukan tindakan sepihak.

Setelah terjadi pengeboman, media selalu membombardir masyarakat dengan alasan bahwa terorisme harus dilawan, seperti yang sampaikan oleh Mentri Pertahanan (Menhan) Matori Abdul Jalil bahwa teroris adalah musuh umat manusia, karena gerakan-gerakan radikal tersebut berlawanan dengan demokrasi. Banyak media cetak maupun elektronik yang memberitakan bahwa pelaku terorisme itu adalah kelompok umat Islam, sehingga masyarakat menjadi takut kepada orang-orang Islam padahal pada kenyataannya pelaku pengeboman tersebut adalah kelompok Islam radikal.

Di Bali, rentetan peristiwa pengeboman itu bukan saja menimbulkan efek ketakutan, tetapi juga retaknya hubungan umat Islam dengan umat Hindu. Sebelum peristiwa tersebut terjadi, masyarakat Bali dikenal sangat toleran terhadap umat Islam. Akulturasi dan toleransi di Bali sudah lama terjadi seiring dengan masuknya Agama Islam, Kristen, Khatolik yang dibawa oleh beberapa etnis dari luar Bali, seperti Jawa, Bugis, Makassar, Sasak.

Wacana Ajeg Bali akhirnya digulirkan pasca tragedi Bom Bali pada 12 Oktober 2002, dapat dipandang sebagai gerakan dari rasa khawatir akan terancamnya ketahanan identitas kultural, ekonomi dan ekologi masyarakat Bali. Pasca terjadinya peristiwa Bom Bali 12 Oktober 2002 dan 1 Oktober 2005 membawa semangat kembali pada tradisi dan kekuatan Bali. Semangat otonomi daerah tersebut diperkuat dengan menjaga Bali membuat Pacalang melakukan penertiban penduduk yang dilakukan kepada penduduk pendatang yang berasal dari luar Bali. Kecurigaan ini diperkuat dengan tertangkapnya Amrozy, Imam Samudra dan tokoh teroris lainnya yang berasal dari luar Bali.

Hingga pada tahun 2009 kecurigaan orang Bali terhadap Islam tidak sedikit yang menganggap bahwa Islam telah melegalkan ajaran-ajaran yang mengandung kekerasan. Hal tersebut dikarenakan pelaku pengeboman mengaku bahwa pengeboman dilandaskan oleh seruan agama, sehingga muncul asumsi dikalangan Hindu bahwa Islam adalah para teroris berkopyah. Tidak hanya kecurigaan yang ditujukan kepada Islam tetapi ada keterbatasan dalam melakukan kegiatan keagamaan seperti kegiatan keagamaan yang melibatkan banyak orang seperti diba'an dan tahlil, begitu juga dalam hal pendidikan, pergaulan dan birokrasi, dan sebagainya.

\section{Pokok Permasalah}

a. Tantangan apa sajakah yang di alami orang Islam pasca peristiwa Bom Bali?

b. Bagaimana peran para Ulama pasca peristiwa Bom Bali?

c. Bagaimana sikap masyarakat Bali terhadap masyarakat Islam pasca peristiwa Bom Bali?

\section{Tujuan Penelitian}

a. Mengetahui tantangan orang Islam pasca peristiwa Bom Bali

b. Mengetahui peran para Ulama pasca peristiwa Bom Bali 
c. Mengetahui sikap masyarakat Bali terhadap masyarakat Islam pasca peristiwa Bom Bali

\section{Metode Penelitian}

Sumber sejarah merupakan segala sesuatu yang terwujud dan tidak terwujud yang berguna untuk menghimpun data dan mengumulkan informasi yang berkautan dengan penelitian sejarah. Metodologi yang digunakan dalam penelitian ini adalah metode sejarah lisan, dengan melakukan wawancara dengan masyarakat Islam dan masyarakat Bali yang merasakan dampak dari peristiwa Bom Bali. Dalam hal ini pemilihan informan sebagai nara sumber menggunakan metode puposive sampling; pengambilan sampel atau informan diambil secara sengaja, peneliti sendiri yang menentukan informan karena pertimbangan tertentu. Namun pemilihan tidak sembarangan melainkan memilih orang atau masyarakat yang terlibat atau mengetahui peristiwa Bom Bali. Jumlah informan tidak ditentukan seberapa banyak tetapi apabila sudah anggap cukup. Ada 11 orang informan masyarakat Islam dan 8 orang masyarakat Hindu. Metode penelitian dan sumber meliputi beberapa tahap antara lain; heuristik, kritik, interpretasi dan historiografi.

\section{Hasil dan Pembahasan}

Islam masuk di Bali diperkirakan pada abad 14 dan 15, salah satu bukti terdapat dalam Kidung Pamacangah yang mengangkat cerita tentang keberadaan sebuah kerajaan di Bali yang berpusat di Gelgel, Klungkung. Arus deras yang menunjukkan masuknya Islam ke Bali adalah dibawa oleh pelaut-pelaut Bugis Makassar setelah perang Makassar pada tahun 1669, orang-orang Bugis ini akhirnya mendarat di Jembrana, Badung dan Buleleng, hingga pada akhirnya ketiga daerah ini kemudian manjadi daerah yang paling banyak terdapat pemeluk beragama Islam.

Kerukunan umat beragama di Bali sudah terjalin dengan baik dengan sistem budaya yang disebut nyama braya yang artinya saudara, kerabat, saudara dekat sehingga teman-teman yang non-Hindu ataupun non-Bali sudah dianggap sebagai kerabat. Salah satu yang bisa diambil contoh wujud kerukunan yang terjadi antara masyarakat Islam dan masyarakat Hindu adalah hubungan sosial seperti perkawinan diantara keduanya, saling menjaga keamana pada saat masyarakat Islam mengadakan acara begitu juga sebaliknya. Selain itu, ada pula suatu kesenian yang menjadi ciri khas dari kampung Islam Kepaon yang disebut dengan kesenian Rodat, kesenian ini mecerminkan perpaduan antara budaya Bali, Jawa, Melayu dan Bugis. Kesenian ini menunjukkan bagaimana interkasi sosial antara umat Hindu dan Islam terjalin dengan sangat baik. Begitu juga berdasarkan hasil dialog tentang kerukunan yang diambil dari ajaran masing-masing agama tersebut menunjukkan kesamaan nilai hidup bersama untuk menciptakan kerukunan, saling berdampingan secara harmonis.

Keanekaragaman masyarakat, budaya dan gaya hidup dapat dijumpai di Bali, salah satunya adalah kota Denpasar merupakan salah satu kota Internasional di Indonesia hingga menciptakan masyarakat yang heterogen. Denpasar merupakan wilayah dengan latar belakang masyarakat dari budaya, agama dan etnis yang berbeda. Menurut data statistik kependudukan menurut agama provinsi Bali, umat Islam memiliki angka terbanyak nomor dua setelah uamat Hindu yaitu sebanyak 225.899 jiwa.

Dampak dari peristiwa Bom Bali mempengaruhi hubungan sosial antara masyarakat lokal dengan para pendatang, dalam konteks ini yang dimaksud adalah pendatang dari luar Bali yang non-Bali 
dan non-Hindu dicurigai sebagai ancaman. Kondisi ini semakin nyata terutama setelah peristiwa Bom Bali tahun 2002 dan 2005. Peristiwa Bom Bali selain menghancurkan perekonomian Bali juga melebar kepada masalah sosial lainnya yaitu kekhawatiran tentang kehidupan beragama. Kartu Ijin Penduduk Sementara (kipem) yang dianjurkan untuk para pendatang sebagai ganti KTP, Kipem menjadi sangat penting untuk hidup di bali bagi para pendatang, apabila tidak punya kipem maka akan menjadi incaran penggrebekan para pecalang. Razia KTP diperketat terutama di pintu masuk pelabuhan Gilimanuk. Keresah lain yang dirasakan masyarakat Islam di Bali seperti terhambatnya pembangunan sarana keagamaan, seperti pembangunan tempat ibadah dan taman membaca AlQuran, selain itu ada kecurigaan yang tujukan kepada masyarakat Islam, adanya kerenggangan hubungan antara masyarakat Islam dan Hindu, hingga ada yang beranggapan bahwa Islam adalah agama yang tidak benar. Dampak Bom yang terjadi dua kali di Bali sangat memberi pengaruh negatif terhadap pariwisata Bali khususnya. Banyak masyarakat Islam yang bergantung disektor pariwisata kehilangan pekerjaan karena kejadian bom tersebut. Begitu juga dengan para pedagang bakso dan sate, yang kurang lebih dua puluh tahun bekerja di Bali mengalami penurunan omset dan pelanggan pasca peristiwa Bom Bali. Pascaledakan bom juga berdampak dikalangan supir taksi yang sehari-hari mangkal diseputar Nusa Dua.

Kegiatan Majelis Ulama Indonesia (MUI) adalah berdimensi dakwa, pasca peristiwa Bom Bali MUI mengeluarkan fatwa bahwa tindakan yang dilakukan oleh para pelaku Bom Bali adalah teroris buka jihad. Dalam fatwa tersebut juga menjelaskan perbedaan mengenai teroris dan jihad. Jihad hukumnya wajib dalam membela agama, sedangkan teroris hukumnya haram, karena merusak, menciptakan rasa takut. Pasca peristiwa Bom Bali MUI provinsi Bali melakukan kunjungan kebeberapa daerah di Bali, malakukan khotbah, pengajian yang bertujuan untuk memeberikan tuntutan kepada umat antara perbuat yang baik dan buruk, selain itu juga mengadakan dialog dan siaran. Forum Kerukunan Antar Umat Beragama (FKUB) melakukan dialog selama dua kali yaitu pada tanggal 14 Oktober 2002 dan 2 November 2002. Dialog ini bertujuan untuk menginformasikan dan arahan sikap umat beragama dalam menghadapi Bom Bali, salain itu juga berfokus pada kearifan lokal Bali yaitu menyama braya. Dua dialog tersebut berhasil menenangkan masyarakat. Salin itu dilakukan juga oleh masyarakat dengan melakukan doa bersama menyatukan pandangan dan merapatkan barisan yang bertujuan untuk mengantisipasi perkembangan masalah yang mengarah kepada isu negative terutama masalah SARA.

Sikap masyarakat Bali dalam menghadapi Bom Bali melihat bahwa peristiwa bom tersebut merupakan masalah kejahatan kriminal yang harus diserahkan kepada pihak yang berwenang. Peristiwa bom yang terjadi bukanlah masalah agama, karena masayarakat Bali yakin dan percaya bahwa dalam ajaran semua agama mengajarkan kebaikan dan tidak ada anjuran untuk menyakiti orang lain. Peristiwa tersebut merupakan ujian dan musibah karena merugikan Bali dan sangat berdampak pada sektor pariwisata. Sekalipun para pelaku pengboman mengatasnamakan agama untuk membenarkan kejahatannya masyarakat Bali tidak ada rasa dendam terhadap masyarakat Islam yang ada di Bali, tetapi hanya mengutuk para pelaku pengeboman tersebut. Ada beberapa 
ajaran Hindu yang dipegang teguh oleh masyarakat Bali untuk hidup rukun dalam kehidupan bermasyarakat antara lain: Tatwam Asi, Atma Tattwa, Tri Kaya Prisudha, Tri Hita Karana, Vasundhaiva Kutumbakam,Sagilik-saguluk Salunglung Sabayantaka, Hukum Karma dan juga kearifan lokal menyama braya. Upacara juga dilakukan pasca peristiwa Bom Bali, Pemlebeh Pemrayasita Durmanggala yang dilakukan pada enam hari pasca terjadi bom yaitu pada Jumat 18 Oktober di jalan Legian Kuta, dan upacara Tawur Agung Pamarisudha Karipubhaya, dengan tujuan untuk memohon ampunan untuk ketenangan para arwah korban, kedamaian dan kesejahteraan bagi masyarakat Bali.

\section{Simpulan}

telah dipaparkan pada bagian sebelumnya, dapat disimpulkan bahwa hubungan antara masyarakat Hindu dan Islam pada masa kerajaan Bali hingga sebelum peristiwa Bom Bali tahun 2002 berjalan sangat baik. Namun, pasca peristiwa Bom Bali ada gejolak hubungan antara masyarakat Islam dan Hindu dan beberapa tantang ayng dihadapi masyarakat Islam.

Masalah tersebut bisa dinetralisir kembali berkat beberapa kegiatan yang dilakukan oleh beberapa forum keagamaan seperti, MUI, FKUB, pemerintah dan juga masyarakat yang terus mengembalikan citra Bali dan hubungan baik antara keduanya. Hal yang sangat berpengaruh untuk mengembalikan hubungan baik antara masyarakat Islam dan Hindu adalah sikap baik yang ditunjukkan oleh masyarakat Bali dalam menghadapi peristiwa Bom Bali.

\section{Daftra Pustaka}

"Warga Diimbau tak Terprovokasi."

Denpost, Senin 14 Oktober 2002.
Ali, Tariq. 2004. Benturan antar Fundementalis Jihat Melawan Imperialisme Amerika. Jakarta: Peramedina.

Ardhana, I Ketut. 2011 Masyarakat Multikultural Bali: Tinjauan Sejarah Migrasi dan Integrasi. Denpasar: Pustaka Larasan.

Data Statistik Penduduk Dati I Provinsi Bali BPS 2010 (data diperoleh dari kantor MUI Provinsi Bali)

Hasbil, "Efek Bom Bali Terhadap Umat Islam Bali”, http://hasbilloloan.blogspot.co.id 12009/04/efek-bom-bali-terhadapummat-islam-bali.html (diakses pada 10 April 2016)

M. Burhanudin, Yudhis. 2008. Bali Yang Hilang: Pendatang, Islam dan Etnisitas di Bali. Yogyakarta: Kanisius.

Made Ngurah, Gusti. 2010. Saling Menerima Dan Menghargai Perbedaan Melalui Dialog Antarumat Beragama Dalam Masyarakat Multikultural. Denpasar: Yayasan Sari Kahyangan Indonesia.

Putrawan, Nyoman. 2011. Pilar Yang Rapuh Bali Yang Runtuh. Denpasar: Pusaka Manikgeni.

Romi, "Muslim Bali Tingkatkan Pertumbuhan Ekonomi Pulau Dewata, SuaraPembaruan",http://www.beritas atu.com/nasional/158783-muslimbali tingkatkan-pertumbuhanekonomi-pulau-dewata.html, (diakses 13 November 2014) 
Setia, Putu. 2005 Mendebat Bali.

Denpasar: Pustaka Manikgeni.

Suryawan, I Ngurah. 2007. Kesaksian Air

Mata: Kisah-kisah Memecah

Senyap. Denpasar: Pusaka Larasan.

Win Wan Nur, "Situasi Umat Islam di Bali Gawat dan Tertekan?," http://.kompasiana.com/winwannur/s ituasi-umat-islam-di-bali-gawatdan-sangat-tertekan (diakses pada 10 April 2016)

Yuliani, Ni Putu. 1993. "Kerukunan Antar Umat Beragama Di Jembrana dan Buleleng 1856-1990: Suatu Tinjauan Sejarah", Skripsi. Denpasar: Fakultas Sastra Universitas Udayana.

Wawancara dengan $H$. Muhammad Taufik As'adi (67 tahun) pada tanggal 23 November 2015 di kantor Majelis Ulama Indonesia (MUI) Provinis Bali, selaku ketua MUI Provinsi Bali

Wawancara dengan Prof. Dr. I Putu Gelgel, SH. M.Hum (61 tahun) pada tanggal 13 April 2017 di Universitas Hindu Indonesia (UNHI) Denpasar, selaku dosen UNHI 